\title{
Soldaterpostkort fra Første Verdenskrig
}

\author{
af Lizette Albak Nielsen
}

Soldaterne i 1. Verdenskrig var flittige til at sende postkort og breve til familie og venner. Mange af disse hilsener er endnu bevaret $i$ offentlige arkiver og private gemmer. Med udgangspunkt $i$ en lille samling postkort $i$ et enkelt privatarkiv undersøges her, hvad man kan læse ud af postkortene og deres billeder. Desuden drages sammenligninger med de tilsvarende soldaterbreve.

Wittenberge, 1915.

Kære allesammen! Klokken er netop 13.30, og vi har lige fået kaffe, sigtebrød og knækpølse. Vi får en god forplejning alle steder, hvis det fortsætter sådan, kan vi ikke få has på al vores flæsk og pølse, som vi har bragt med, og det er ikke så lidt. Forhåbentligt går det jer alle godt, ligesom jeg. En kærlig hilsen til jer alle. Fra jeres kære far Eduard.'

Kortet til familien skrev Eduard Nicolai Jacobsen, én af de sønderjyder, som gjorde tysk krigstjeneste i 1 . Verdenskrig, undervejs til Østfronten. I sønderjyske soldaters breve hjem kan man få indblik i deres syn på krigen og den tvungne krigsdeltagelse. Man kan se, hvilke følelser og håb de nærede, $\mathrm{og}$ få en fornemmelse af, i hvor høj grad det danske sindelag kom til udtryk. Mange var følelsesmæssigt splittet mellem egen danskhed og pligten til at være tysk soldat. En nogenlunde komplet korrespondance findes sjældent bevaret, dog blev der allerede i 1915 udgivet et bind med soldaterbreve under titlen "Sønderjyske Soldaterbreve fra Øst- og Vestfronten, skrevne til Slægt og Venner i Hjemmet«. Efter krigen udkom en mindre samling, "Krestens Breve udgivne af hans Moder، i 1919, og siden blev enkelte udvalgte breve fra Thorvald Dau til forældrene bragt i Sønderjyske Aarbøger (1930).

Men om de utallige postkort, som soldaterne sendte hjem, er der intet samlet publiceret. Jeg har villet undersøge, om postkortene indeholder tilsvarende reflektioner over krigen og soldaterlivet, eller om de havde en anden funktion end brevene. Til det formål har jeg gennemgået Ed. Jacobsens postkorthilsner hjem fra krigsårene. Desuden kan man via illustrationerne på de postkort, som blev uddelt vederlagsfrit til soldaterne, belyse hvilke idealer og værdier den tyske stat søgte at formidle til soldater og civilbefolkning. 
Sigtet med artiklen har også været at skildre krigsforløbet for en menig dansksindet, sønderjysk soldat, gennem en jævn håndværker og familiefader, som ikke indtog en position i det nationale danske arbejde. Jeg har ønsket at vise kontrasten mellem en familiefaders opfattelse og oplevelse af situationen udledt af hans postkorthilsner hjem m.m., over for den officielle propaganda, udtrykt ved de postkort, som soldaterne fik udleveret gratis, men som Ed. Jacobsen ikke anvendte. Krigens konsekvenser fysisk, som mentalt og økonomisk vil blive belyst for ham og familien, og afslutningsvis inddrages supplerende kildemateriale.

\section{Kildemateriale og personlige data}

Murer Eduard Nicolai Jacobsen (1886-1963) fra Bredebro nord for Tønder blev indkaldt til tjeneste i Flensborg d. 24.3.1915 som Landsturm Rekrut. ${ }^{2}$ Fra hustruen Cathrine Marie Jacobsens dødsbo (1888-1980) er bevaret dele af hans korrespondance fra årene 1915-18 til hende og de mindreårige børn Peter og Anna Helene. Korrespondancen består af 26 postkort, mens ca. fem kort er

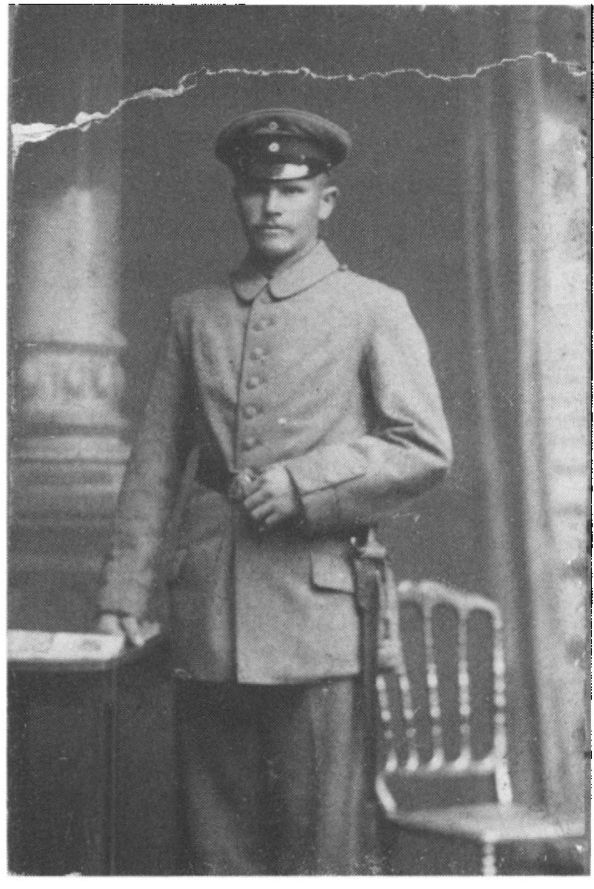

Murer Eduard Nicolai Jacobsen fotograferet som soldat under 1 . Verdenskrig, ca. 1915-18. Foto F. Flarup, Flensborg. Privat eje. 
bortkommet, og samtlige breve savnes. Desuden findes en halv snes ubeskrevne soldaterpostkort, samt hans "Militärpass«, "Soldbuch« og personlige dokumenter. "Militärpass«'et giver oplysning om indehaverens personlige data: hans tjenestested, hærenhed, tiltrædelses- og fratrædelsesdatoer. Der er angivelse af kampdeltagelse, kvæstelser og lazaretophold, og ydermere anmærkning om soldatens beføjelser, udmærkelser, opforsel og eventuelle straffe. "Soldbuch «'en indeholder ejerens personlige data, angivelse af orlov og sygdomsperioder, samt lønudbetalingsmærker (i et afklipningssystem).

Hjemmet var dansktalende, selv om kortene er skrevet på tysk, hvilket skyldes, at han som dreng havde tysk skolegang i Sydslesvig. I barndomshjemmet ved Neukirchen (Nykirke) blev der talt friser-tysk og dansk, da hans dansksindede forældre kom fra de frisiske øer, Halligerne. Især moderen gjorde en aktiv indsats for at holde det danske sprog levende i familien og læste dansk med børnene.

Ed. Jacobsen var i murerlære i 1902-5 i Rodenäs (Rødenæs) og arbejdede efter læretiden forskellige steder i landsdelen. Årene 1907-1910 tog han på valsen til Tyskland, Østrig og Schweiz efterfulgt af et længere ophold på Vallekilde håndværkerhøjskole. Det følgende år, 1912, blev han gift med Cathrine Marie Svendsen og nedsatte sig som selvstændig murer i Bredebro.

Ed. Jacobsens krigsdeltagelse og lazaretophold kan spores ved hjælp af hans »Militärpass« og »Soldbuch« kombineret med postkortenes afsenderadresser, poststempler og konkrete meddelelser. ${ }^{3}$

\section{Østfronten}

Efter cirka tre måneders militærtræning som rekrut på Flensborg kaserne blev Ed. Jacobsen sendt til Østfronten, hvor han blev overført til 7. Kompagnie, Reserve-Infanterie-Regiment $208 .{ }^{4}$

Ruten gik med troppetransport til Wittenberge ved Elben, videre til Dobrilugk mellem Berlin og Dresden, og derfra via Østrig ind i det sydlige Polen nær grænsen til Ukraine:

\subsubsection{5.}

Kære kone og børn. Jeg sender jer hermed en kærlig lykønskning ${ }^{5}$ fra Dobrilugk Nieder-Lausitz Brandenburg. Har du fảet de andre kort? Jeg er rask og håber det samme for jer. $(. .)^{6}$

\subsubsection{5.}

Kære kone og børn. Jeg sender jer hermed en kærlig hilsen fra Østrig. Jeg er stadig på rejse og har det godt. Men har igen fået 
té, ost og brød. Jeg håber, at I alle er sunde og glade. Hils alle mange gange fra mig. Kærlig hilsen jeres far. Lev vel og på gensyn. Eduard.

Rzeszów 20.7.15. ${ }^{7}$

Min elskede kone og børn. Far Eduard sender jer en kærlig hilsen fra Rzeszów. (...) Jeg ved ikke, om du får alle kortene, som jeg skriver. Det går jo ikke altid så regelmæssigt. Jeg har det stadig meget godt. Her har russerne også været et år $\left(?^{8}{ }^{8}\right.$ ser ikke godt ud. (...)

Den tyske hær indledte maj 1915 en storoffensiv på Østfronten med gennembrud ved Gorlice-Tarnów (Galicien sydøst for Krakow). Midt i juli satte tyskerne ind med en fornyet angrebsbølge (operationsplan Falkenhayn ${ }^{9}$ ): De sydlig stående tropper, den 11. Armé, Bugarmeén og den østrig-ungarske 4. Armé, skulle angribe i nord-østlig retning mod Brest-Litowsk; de nordlige armeér (8. og 12. tyske Armé) skulle gennembryde Narewlinien og over Lomza trænge frem til Warszawa østfra, og endelig skulle den vestlige 9. Armé og Armégruppe Woyrsch angribe Warszawa frontalt. Offensiven varede fra maj til oktober med tysk besættelse af Litauen, Kurland, Polen, generobring af Galicien og tyske styrker inde i Rusland. Henved 850.000 russiske soldater blev taget som krigsfanger. For en mere detaljeret oversigt og gennemgang af felttoget se Peter Graf Kielmannsegg, Deutschland und der Erste Weltkrieg, især kapitel 7, Der Feldzug gegen Russland im Jahr 1915 (p. 78-88).

Nære øjebliksbilleder og personlige situationsbeskrivelser af felttoget på Østfronten får man f.eks. gennem brevene: Fra Østfronten, Da jeg blev såret i Polen, Efter Lowicz' Fald, Da Russerne blev drevet ud af Østpreussen, Fra et af de store Slag i Østpreussen, Paa Lazaret i Rusland, Erobringen af Szawle samt Efter Slaget (i bogen »Sønderjyske Soldaterbreve«).

Hen på sommeren deltog Ed. Jacobsen i flere træfninger og slag på polsk territorium, først ved byen Krasnystaw sydøst for Lublin tæt på den ukrainske grænse. ${ }^{10}$ Dernæst var han med $i$ en træfning ved den lille by Biscupiec nær Olsztyn (Allenstein) nord for Warszawa. Hovedangrebet på sydfronten fandt sted fra midten af juli med heftige kampe ved Cholm - Lublinlinien, hvor han deltog i området mellem floderne Wieprz og Bug. Trods massiv russisk modstand faldt Lublin d. 30.7 og Cholm d. 1.8. De hårde, blodige kampe i det sydlige Polen under den tyske offensiv og den tyske og russiske taktik omtaler Ed. Jacobsen ikke, vel delvis fordi han ikke kunne eller onskede at skrive herom.

Under slaget d. 2. august ved den mindre by Majdan lige nord for Rzeszów 
blev han ramt af skud $\mathrm{i}$ venstre lår og indlagt til behandling på lazaret $\mathrm{i}$ Zwickau syd for Leipzig:

Zwickau, Res. Laz. II, 26.8.15.

Kære kone og børn. Jeg har lige fået en pakke fra dig med dit dejlige bagværk i. Tusind tak for det. Det var slet ikke tørt. Jeg ved ikke, hvor jeg helt ærligt har smagt noget bedre. Det smagte helt nybagt. (...) Jeg fik også en pakke med cigarer fra Nicolai i morges og ligger lige nu og ryger på en skøn Havannacigar. Jeg har det godt. Hils vores søde børn og Vater. ${ }^{11}$ Også en kærlig hilsen til dig. Fra jeres kære far. Lev vel.

De næste par måneder var han på lazaret, indtil han blev raskmeldt og udskrevet til tjeneste $i$ Landsberg ved Warthe i nærheden af Halle:

Zwickau, Res. Laz. II, 22.9.15.

(...) Jeg skal sikkert fremstilles igen i morgen, men jeg tror ikke, at jeg kommer herfra denne uge. (...) Jeg kan forhåbentligt snart besøge jer. (...)

Zwickau, Res. Laz. II, 28.9.15.

Jeg blev ikke fremstillet her til morgen og kommer helt sikkert ikke videre denne uge. Men jeg har det jo også godt, hvor jeg er. Jeg skriver i morgen til mor og søster Anna. (...)

Zwickau, Res. Laz. II, 28.10.15.

Kære allesammen. Hjertelig tak for dit kærlige brev. Jeg bliver udskrevet herfra fredag middag som garnisonstjenesteanvendelig. ${ }^{12}$ Skriv derfor ikke indtil jeg har skrevet min adresse fra Landsberg. (...)

I Landsberg blev Ed. Jacobsen d. 31.10 .15 overført til Genesenden-Kompanie II E./I.R. $48 .{ }^{13}$ :

Landsberg, 26.11.15

Jeg er blevet udskrevet som krigstjenesteanvendelig. Jeg meldte mig i morges med mit ben og fik en dags skåning. Men én dag gør det vel ikke bedre. (...)

Han kom d. 4 december til Komp. II E.B./I.R.48 sammesteds. I "Militär- 
pass «'et er der ikke angivet kampdeltagelse for vinteren 1915/16, men d. 8 . januar er han atter indlagt til operation. Kvæstelserne svarer ikke overens med dem, han fik ved Majdan, og det forekommer derfor sandsynligt, at han atter har været i kamp:

Landsberg, 14.1.16.

Kære kone og børn! Lægen og lederen af hospitalsafdelingen har lige været her på sygesalen for at se, hvem der ville have et kursus i bogføring eller regnskab og lignende. Men da de kom til mig, mente lægen, at det ikke kunne betale sig, fordi jeg jo snart skal opereres, hvornår ved jeg endnu ikke sikkert. Jeg tænkte nu mit. Han sagde heller ikke, hvad de vil operere. Skulder eller ben eller hofteled. Jeg er igen blevet røntgenfotograferet, billederne var meget tydelige sagde de, jeg har endnu ikke set dem. Möller fra Tingleff blev igår udskrevet som tjenesteuanvendelig, hos ham sidder kuglen jo i ryggen. Jeg synes det ser dystert ud. Chr. ${ }^{14}$ skriver også, at han vil være glad, bare de kan komme ud af Rusland. Han må jo ikke skrive, hvad der sker hos dem i denne tid. (...) Forhåbentligt har I det alle godt. På glædeligt gensyn i den elskede hjemstavn. Lille Peter leger sikkert med snebolde i denne tid. Hils de kære små mange gange. Jeres kære far.

I marts kom han til diakonisseanstalten i Flensborg for at blive restitueret:

Flensborg, 4.5.16.

(...) Jeg var idag til undersøgelse for, om jeg er våbenfør, men skal komme igen om 8 dage. (...)

Flensborg, 8.5.16.

Kære kone og børn. Jeg er kommet godt hertil. Jeg har lige fået kort fra Boye. Ham går det endnu godt. Hilsen til vore kære små og Vater. Jeg mødte Hans Lindholm i Tønder. Han havde 14 dages orlov. Jeg skriver brev i morgen. ${ }^{15}$ På glædelig gensyn. Jeres Eduard.

Om sommeren blev han udskrevet og rejste tilbage til Landsberg over Berlin:

Landsberg, 20.7.16.

(...) Lige for at fortælle jer, at jeg er godt ankommet. Jeg var i 
formiddags hos C. og F. i Berlin. Skal selvfølgelig hilse mange gange. $(. . .)^{16}$

I Landsberg kom han d. 10.8.16 til 1. Kompanie, II E.B./I.R. 48, som geværskytte (»Musketier«).

\section{Landsberg, 1.9.16.}

Blot for at fortælle jer, at min orlov ikke er bevilget. Jeg havde allerede en anelse om, at den ikke ville blive givet. Forhåbentligt lykkes det bedre næste gang. Kærlig hilsen til jer alle. Din mand Eduard.

Orloven kom allerede d. 1. oktober og gjaldt to uger frem.

Om efteråret blev han sendt til Berlin:

Landsberg, 5.11.16.

Kære lille Anna! Jeg sender en kærlig hilsen fra Landsberg. Jeg er her vel idag for sidste gang. I morgen tidlig er vi allerede $\mathrm{i}$ Schöneberg. Mor vil jo nok læse det for dig. Hils hende mange gange. På glædelig gensyn. Din far. Eduard.

Allerede dagen efter kom en hilsen fra Berlin:

Berlin-Schöneberg, 6.11.16.

Kære kone og børn! Vi tiltrådte her i dag til morgen kl. 7; kl. 6 var vi på banegården. Vi kommer sikkert til en fangelejr i Berlin. Så går det jo heller ikke helt galt. (...)

Berlin- Schöneberg, 7.11.16.

Kære kone og børn! Vi er stadig her i Schöneberg, Papestrasse. Jeg bor Herbertstrasse 5 sammen med to andre de sidste to nætter, hvor vi er her. Jeg har ikke lang vej at gå. I eftermiddag skal vi sikkert i uniform. Hvornår det går løs, ved vi endnu ikke. Det skal nok gå godt. Forhåbentligt har I det godt, ligesom jeg. Kærlig hilsen og på gensyn. Far, Eduard.

Det er umuligt på grundlag af hans "Militärpass« og kortenes indhold at se, hvilke opgaver han og de andre soldater varetog, om de f.eks. udforte vagt- 


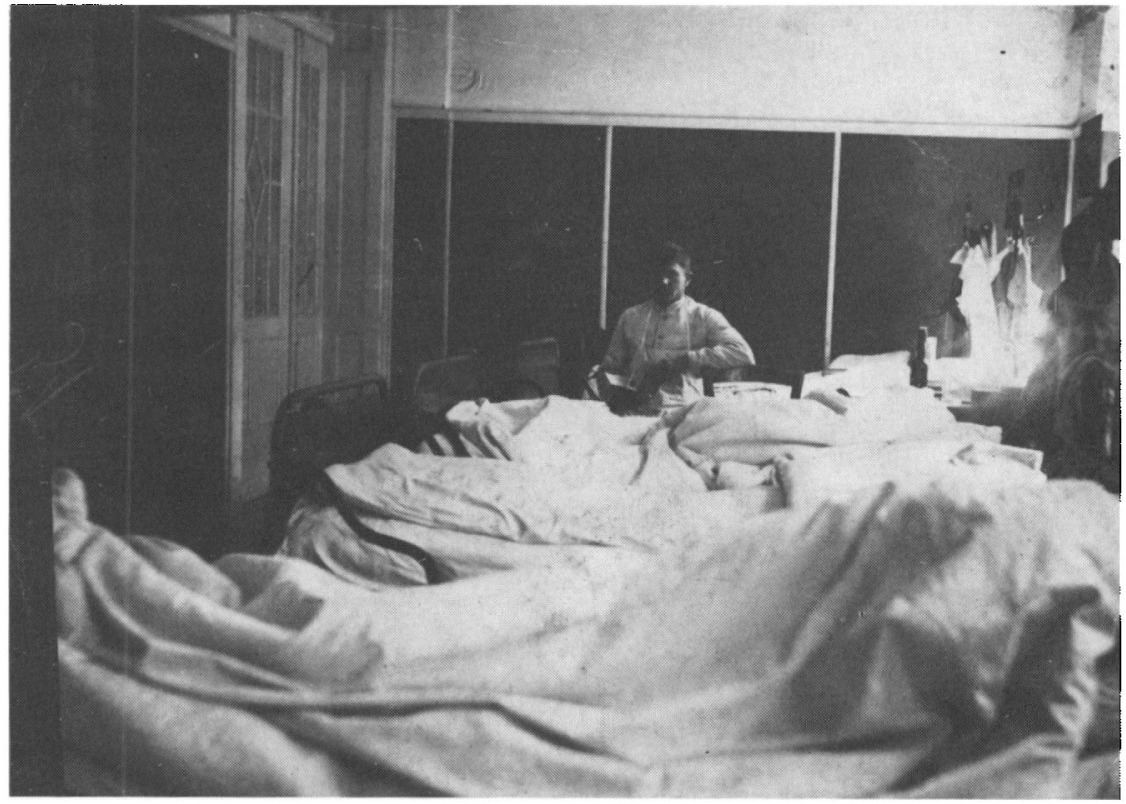

Eduard Nicolai Jacobsen fotograferet som sanitetssoldat $i$ Landsberg Reservelazarett $I$, afd. Adlergarten, 1917-18. Privateje.

eller sanitetsarbejde. Men opholdet var af kort varighed, da han i begyndelsen af det nye år var tilbage i Landsberg, hvorfra han d. 2. januar 1917 skrev en fødselsdagshilsen til sin kone.

Midt i januar blev han "Militär Krankenwärter«, dvs. militær sygepasser eller sanitetssoldat på Landsberg Reservelazarett I, afd. Adlergarten, ${ }^{17}$ der var indrettet $i$ en tidligere danserestaurant ved en skovbevoksning. Arbejdet omfattede patientpleje: hjælp til sengeliggende patienter med vask og personlig hygiejne, bringe mad og drikkevarer, skifte forbindinger, portørarbejde, o.lign. Indimellem var han med som sygepasser, når patienter skulle transporteres med tog til lazaretter andre steder eller bringes til Landsberg:

Dortmund, februar 1917.

Kære kone og børn! Jeg sender jer en kærlig hilsen fra Dortmund. Forhåbentlig har I det bedre igen. Vi har allerede afleveret patienterne og er på vej til Berlin. Kærlig hilsen og på glædelig gensyn. Jeres Eduard.

På samme tid skrev han en "god-bedring« hilsen til datteren. Teksten bringes uoversat, så man kan få et indtryk af kortenes originale sprogtone: 
Landsberg, 6.2.17.

Liebe kl. Anna wie gehts dir, wird es nicht ein wenig besser mit dir, dass wünsche ich dir ja von Herzen. Sei nun herzlich gegrüsst von deiner Pappa, grüsse auch Mamma, kl. Peter u. Grossvater.

Næsten frem til krigsafslutningen fungerede han som sygepasser ved Landsberg Reservelazarett I. Den sidste hilsen, som findes, er sendt herfra d. 10.8.18 med afsender M.K.W. Jacobsen, Adlergarten, og af "Soldbuch«'en fremgår, at han havde »Arbeitsurlaub« fra d. 13.10-9.11.18.

Hen på det sidste krigsår d. 16. juni fik Ed. Jacobsen tildelt jernkorset af II. klasse ${ }^{18} \mathrm{og}$ blev to dage senere fritaget for militærtjeneste på grund af sin »in Dienste des Vaterlandes erlittene Verwundung ${ }^{19}{ }^{19}$

\section{Postkortenes indhold og funktion}

Det var gratis at sende feltpost, incl. småpakker op til $1 / 2$ kilo, og soldaterne fik uddelt kort vederlagsfrit. Ringe økonomi skulle ikke hindre soldaterne og deres familier i at holde skriftlig kontakt med hinanden. Det gavnede moralen både på hjemme- og militærfronten.

Kortene var åbne forsendelser, og man kan derfor ikke forvente at finde udtalelser af kontroversiel art med kritik af den førte tyske politik og landets militære engagement. Det var ikke tilladt at meddele forhold, som blev anset for militære hemmeligheder, f.eks. nøjagtige tidspunkter for troppetransporter og deres omfang. Afsenderen risikerede censurering af posten og ubehageligheder; selvcensuren har sikkert været temmelig effektiv.

Postkortenes primære funktion var at være hurtige livliner tilbage til konen og familien, og enkelte er faktisk hastigt nedskrevet under togtransport. Formålet var at give livstegn og berolige (»jeg er sund og rask ()), nogle hilsner begynder simpelthen med sætningen, "Liebe Frau und Kinder. Bin ja gesund und munter«. Hilsnerne lyser trods ordknapheden af ømhed og længsel efter konen og børnene. Sprogtonen virker sine steder tilstræbt positiv. Frygt og smerte udtrykkes ikke, ligesom hændelser og forhold, som kunne opskræmme familien, udelades, da det formålsløst blot ville øge ængstelsen hjemme. En holdning Ed. Jacobsen ikke var ene om, som det fremgår af T's brev d. 26.10.14 fra Østfronten i bogen "Sønderjyske Soldaterbreve«:

Gid Krigen snart var til Ende. Man skal være Vidne til saa megen Elendighed. Jeg kunde skrive saa uendelig meget hjem om det; men det er jo kun til liden Nytte. 
Desuden har kortene en vanlig funktion som meddelelsesmiddel med kortfattede konkrete oplysninger om ankomst og afrejse, adresseændringer, orlovsafslag, pakkemodtagelse m.m.

At kortene er af en anden karakter end brevene, ses tydeligst af den hilsen, han skriver d. 14.1.16 (tidl. citeret), mens han ligger på lazaret for at blive opereret. Kortet er et dobbeltkort sendt i kuvert som lukket forsendelse, og heri kommer bekymring og uro klarest frem. Meddelelser, tanker og følelsestilkendegivelser af mere privat karakter var forbeholdt brevene, derimod skulle kortene kunne læses af familien og omgangskredsen, ofte tilføjes en hilsen til enkelte familiemedlemmer og venner.

Man sporer ingen sympati for krigen eller soldatergerningen, og sproget er uden begejstring over krigsheld, men også uden beklagelse over modgang. Sym- og antipatier tilkendegives næsten ikke, hvilket kan tolkes som et manglende engagement $\mathrm{i}$ krigens forløb, men nok ydermere er en følge af den åbne postforsendelse.

Han ytrer ingen nationale følelser. Den eneste undtagelse er, når han til konen et par gange udtrykker håb om, at de snart igen skal ses i den elskede hjemstavn: "Auf frohes Wiedersehen in der lieben Heimat $4 .{ }^{20}$ En yderst afdæmpet og ukontroversiel hentydning til længslen efter Sønderjylland og hjemmet. Modviljen ved at være soldat $\mathrm{i}$ en krig, han som dansksindet sønderjyde følte uvedkommende, viser sig ikke ved kritik, men snarere gennem det han ikke skriver, og de gratis tildelte kort, han undlader at afsende.

\section{Illustrationer på kortene}

De beskrevne kort er prospektkort med by- og landskabsmotiver, samt enkelte børneportrætter. Alle ganske neutrale og nydelige. Men der findes også en halv snes ubeskrevne kort med krigen som tema, hvoraf nogle er tysk-nationalistiske med en vis krigsforherligende tendens. Et indtryk, der visse steder forstærkes yderligere af de påtrykte vers. For at uddybe denne karakteristik, vil jeg analysere følgende illustrationer: a. Vagtpost, b. Der Kaiser in Lyck, c. Seemannnstreue og d. Regiment 208. Mange af kortene blev udleveret gratis, og det gjaldt helt sikkert dem fra den sidste kategori, der er fortrykt »Feldpostkarte« (soldaterpostkort). Disse har Ed. Jacobsen ganske vist gemt, men undladt at sende, og heri kan man måske se en skjult protest.

\section{a. Vagtpost.}

I et vinterlandskab står en tysk soldat vagt $i$ et granklædt skovbryn, og til hest lige bag ham er en lys rustningsklædt ridder med åbent visir. Ridderen 


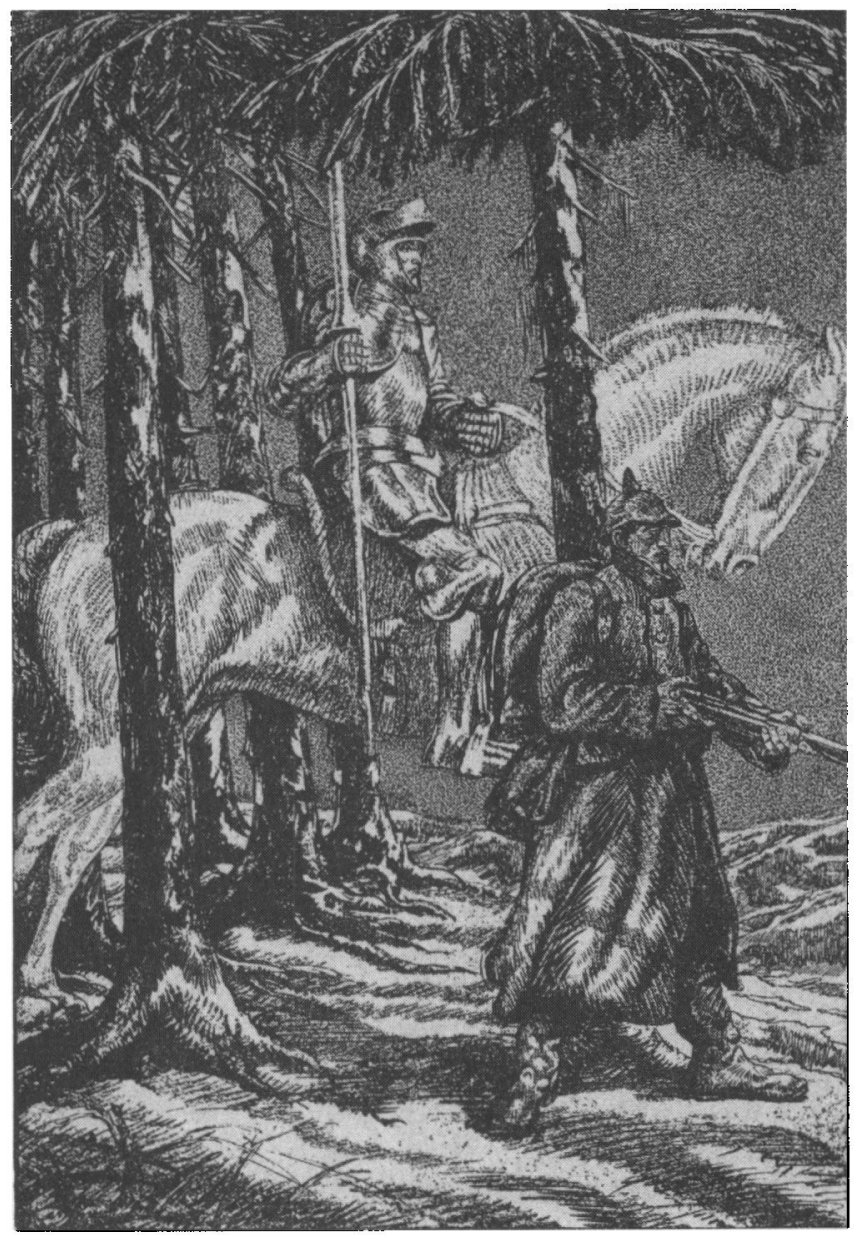

a) Vagtpost

på sin hvide hest er centralt placeret $\mathrm{i}$ billedet. Både han og soldaten er bevæbnede med henholdsvis lanse og gevær, og de har begge opmærksomheden rettet mod eventuelle fjendtlige angreb.

Sammenkædningen af vagtposten og ridderen signalerer, at soldaten lig middelalderens grals- og korstogsridder kæmper for og værner om en hellig sag, her: Tysklands åndelige og materielle værdier. Fædrelandets frelse. Krigen udkæmpes ridderligt, og er ret- og renfærdig. Egenskaber som ofte knyttes til riddermyten - heltemod, troskab og retfærd - forbindes med nutidens soldat. De er begge helte. Motivet forsvarer indirekte den forte krig. 


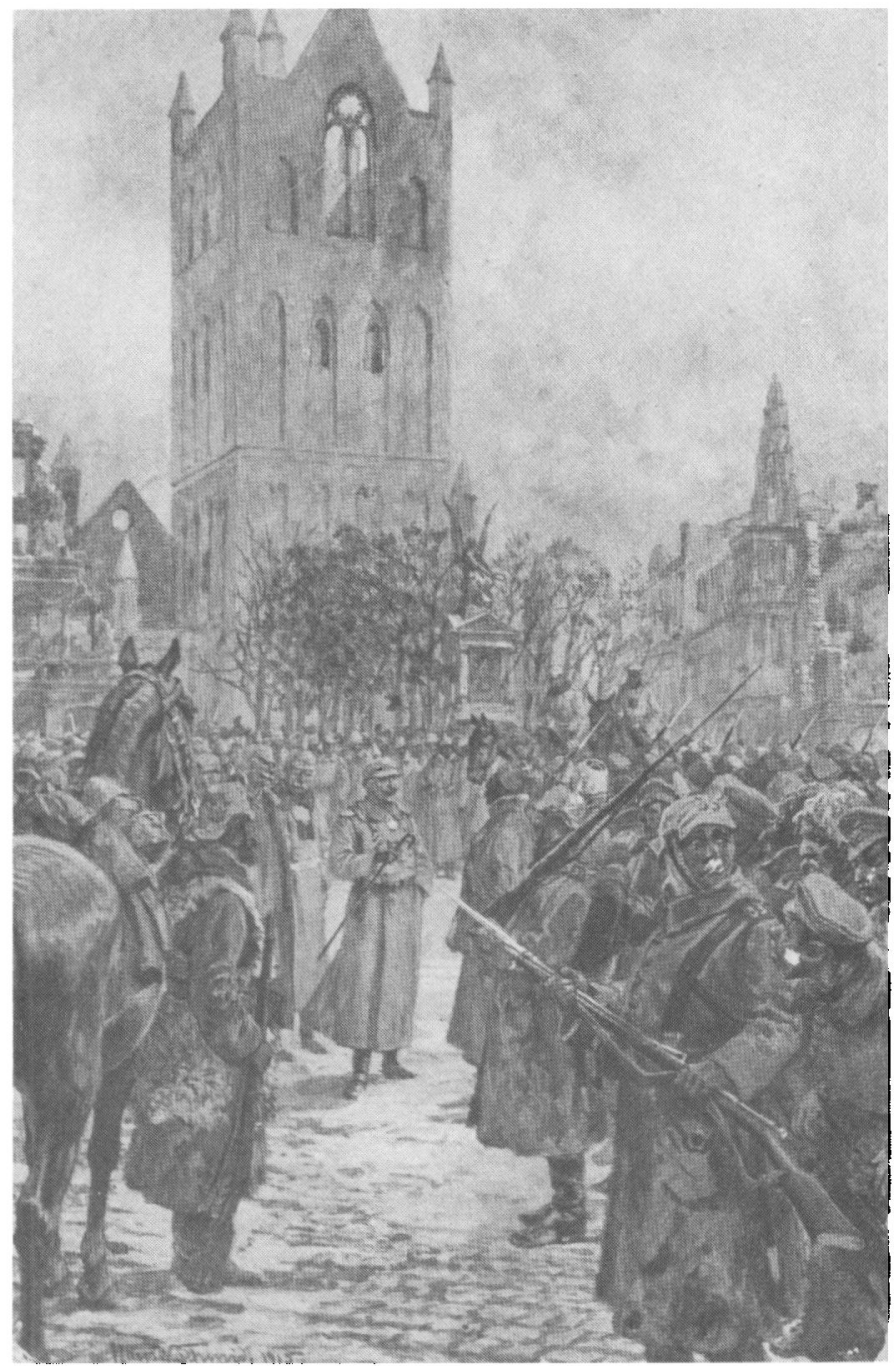

b) Der Kaiser in Lyck

\section{b. Der Kaiser in Lyck. ${ }^{21}$}

På torvet i Lyck står den uniformerede kejser i samtale omgivet af sine soldater; han er hovedpersonen og centrum for opmærksomheden. Der er en åbning $\mathrm{i}$ menneskemassen, så beskueren har frit udsyn mod ham. Bag kejseren rager et højt bastant kirketårn op over byen, der bærer præg af krigshandlinger med sønderskudte og brandhærgede huse. 
En mulig tolkning er, at situationen skal vise kejseren på inspektion $\mathrm{i}$ krigszonen, hvor hensigten er at fremhæve hans aktive deltagelse med omsorg for folkets og hærens velfærd. Ligesom det solide kirketårn trods fjendtlige angreb stadig står, er han urokkelig i kampen, og hans viljefasthed indgyder soldaterne mod.

\section{c. Seemannstreue.}

Maleri af Hans Bordt med digt efter maleri af Heinrich Röser.

Sceneriet skildrer et synkende, tremastet skib, der saluteres farvel. Kompositorisk er billedfladen opdelt $i$ to halvdele med skib og mennesker (frelse, liv) i venstre side; hav og forlis (undergang, død) i højre. Farvekontrasterne er hvid mod sort/blå med ganske lidt rødt. Kunstneren spiller bevidst på det kontrastfyldte i motivets udformning og farvevalg.

Billedet er dramatisk og bevægelsesfyldt: Matroserne hilser farvel fra naboskibets agterstavn ved at kippe med marineflaget og vinker med huerne. Officeren gør honnør for skibet, som har stæunen under vand, og er på vej til at krænge over. De ser i retning af katastrofen bort fra beskueren, hvis blik ledes samme vej og inddrages til en medleven. Naturen afspejler tabet med høj bølgegang, blæst og skydække. Motivet appellerer til basale følelser som sorg over forliset, og medfølelse iblandet med beundring for mandskabets handlekraft og mod. 
Bagsidedigtet "Der letzte Gruß« fortæller om den vinterdag (16. dec. 1914), da "Avesha" blev beskadiget $i$ kamp med den engelske flåde. Krigsmateriellet blev bragt i sikkerhed, og skibet sænkes af dets egen besætning, for at det ikke skal tilfalde fjenden. Mandskabet reddes over på følgeskibet og tager fra dækket afsked med "Avesha«. Digtet er holdt i et svulstigt, men malende billedrigt sprog. "Avesha« omgærdes med kærlighed, det tiltales og begrædes, som en mistet ven:

"Drauf bohrt die Mannschaft in stiller Pein

Avesha zwei Löcher ins Herz hinein.» $(2,7-8)$

»Fahr wohl, Getreue, du bleibst uns im Sinn

Für alle Zeit!« $(2,10-11)$

"Schlaf wohl, Avesha!« $(3,9)$

d. Regiment 208 .

Forsiden er et lejligheds- og mindedigt over slaget ved Belgrad. ${ }^{22}$ Digtet indrammes af en bred egeløvsranke prydet med jernkors:

\section{Regiment 208}

bei

Belgrad am 7. und 8. Oktober 1915.

Wer nennt die Tapfern, die die Wege gebahnt

In jener Gewitternacht?

Die die Fluten der Save durchquert, und im Sturm

Das Ufer vom Feind frei gemacht? -

Stolz sei es für alle Zeiten gesagt:

Die Helden von Zweihundertacht!

Wer nennt mir die Stürmer der Banovo-höh?

Wer brach dort des Feindes Macht?

Und wieder ruf' ich: $M$ e i n Regiment!

Die Helden von Zweihundrertacht!

Wer sind jene Braven mit bleichen Mund,

Die man senkte in Grabes Nacht?

Das sind die Tapf'ren, Euch sei es kund,

Die Helden von Zweihundertacht! 
Weint nicht in der Heimat, tragt würdig die Not!

Ihr sterbender Mund hat's gesagt:

Für Euch gingen freudig sie in den Tod,

Die Helden von Zweihundertacht!

Fritz Kühlewindt, 10. Komp.

I digtet hyldes de tapre soldater, der under angreb indtog fjendens stillinger, og gav deres liv i kampen. Der spørges gentagende retorisk, hvem disse soldater var. Svaret gives i omkvædet: Det var heltene fra 208 ("Die Helden von Zweihundertacht! $\lll$ ), og samtidig forfatterens eget regiment ( $» M$ e i n Regiment ()$_{.}{ }^{23}$ Til sidst henvender han sig direkte til de efterladte hjemme: De skal ikke græde, men bære tabet med værdighed. De faldne gik glade i døden for deres skyld.

Digtet svinger mellem det dystre og patetisk højstemte. Kunstgrebet med at lade naturen afspejle følelser og hændelser anvendes atter her ved at lade angrebene foregå i uvejrsnætter. Sproget indeholder faste udtryk og billeder, som "gå glade i døden« og "gravens nat«. Det er tydeligvis et amatørdigt, dog med en vis appel og slagkraft gennem de gentagne spørgsmål og det faste omkvæd. Forfatteren er selv følelsesmæssigt involveret i tragedien, men viser trods sorgen over tabet stolthed ved at være soldat og tilhøre et heltemodigt regiment.

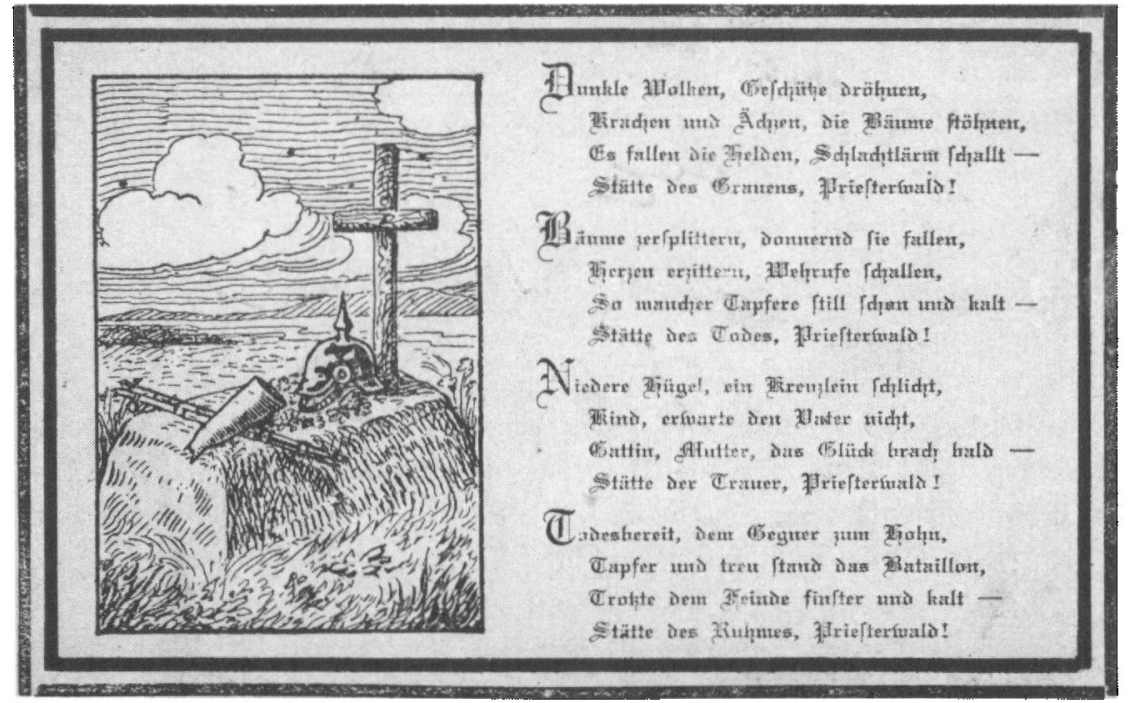

e) Soldatergrav 


\section{e. Soldatergrav.}

De kort, hvis motiver jeg indtil nu har analyseret, er ikke blevet sendt. Imidlertid fik Cathrine Marie Jacobsen ét postkort med krigsmotiv fra Ed. Jacobsens aldre, indkaldte bror Peter. Kortet (28.2.16) er fortrykt »Feldpostkarte« og er illustreret med en soldatergrav, hvor der er rejst et simpelt trækors. Ovenpå graven er der symbolsk lagt et knækket gevær sammen med pikkelhue, og ved billedet står et minde- og hyldestdigt:

"Dunkle Wolken, Geschütze dröhnen, Krachen und Ächzen, die Bäume stöhnen, Es fallen die Helden, Schlachtlärm schallt-« $(1,1-3)$

"Kind, erwarte den Vater nicht, Gattin, Mutter, das Glück brach bald Stätte der Trauer, Priesterwald! $\aleph^{24}(3,2-4)$

\section{"Todesbereit, dem Gegner zum Hohn, Tapfer und treu stand das Bataillon, Trotzte dem Feinde finster und kalt - Stätte des Ruhmes, Priesterwald!«. (4,1-4)}

Naturen vånder sig. Heltene dør. Dødsberedte, tapre og tro kæmper bataljonen mod fjenden og falder. Digtets udsagn og billedsprog lægger sig tæt op ad de øvrige analyserede digte, men med den markante undtagelse, at de personlige tab og sorgen tydeligt udtrykkes. Barnet mister sin far, hustruen manden og moderen sonnen, hele tonen i digtet er dyster.

\section{Konklusion på billed- og digtanalyse}

Kortenes motiver og digte formidler en ideologi, der dyrker helten og hylder den tapre handling, hvor krig er heroisk og soldater heltemodige. Deres mod, styrke, troskab, pligtfølelse, ære og fædrelandskærlighed besynges. Krigslede, menneskespild og meningsløshed tages ikke op som tema hverken i billeder eller tekst, derimod er det tilladeligt at tematisere familiernes tab ved dødsfald. Det grundlæggende syn er imidlertid, at tabene ikke er forgæves, fordi soldaterne dør i selvopofrende kamp for fædreland og hjem. Krigen retfærdiggøres og soldatergerningen idealiseres; en død tysk soldat er næsten per definition en helt.

Med Ed. Jacobsens uheroiske holdning til soldaterlivet og krigen er det ikke svært at se, hvorfor disse postkort aldrig blev sendt. 


\section{Hjemkomst}

Kort før julen 1918 blev han hjemsendt fra lazarettet i Flensborg. ${ }^{25}$ På grund af et stærkt svækket helbred som følge af de tidligere kvæstelser blev han tilkendt invalidepension, fordi man skønnede, at erhvervsevnen var nedsat med 30 pct. ${ }^{26}$ Beløbet udgjorde 35.25 mark månedlig, og sagen skulle efterprøves igen i 1921. Krigsdeltagelsen medførte også et økonomisk tab, da murervirksomheden ikke kunne videreføres under hans fravær. Han måtte arbejde for andre håndværksmestre, indtil helbred og økonomi var så stabiliseret, at virksomheden kunne genopbygges. Først i begyndelsen af 1936 nedsatte invalideretten pensionen til $18,75 \mathrm{kr}$. mdl., så den svarede til en erhvervsnedsættelse på 15 pct, ${ }^{27}$ og inden årets udgang bortfaldt invaliderenten helt. ${ }^{28}$ Det var dog ikke udtryk for, at han var uden fysiske mén; resten af livet led han periodisk af stærke smerter $i$ benet og måtte ofte anvende stok. Lægerne havde ikke fundet det forsvarligt at fjerne to kugler.

Årene var svære for konen, der alene skulle sørge for to småbørn, en lam far og invalid svoger. Samtidig var der vareknaphed og rationering med mangel på madvarer og andre dagligdags fornødenheder som koks, petroleum, sæbe o.lign. Dertil kom spekulationerne og angsten for mandens liv og helbred. Sliddet med at forsørge familierne fik nogle kvinder til at bryde helbredsmæssigt sammen. ${ }^{29}$

Krigsoplevelserne undgik Ed. Jacobsen helst at tale om; de var næsten tabubelagte. Det eneste han gang på gang vendte tilbage til, var en vens tragiske død ved fronten lige efter våbenstilstanden. Krigen ændrede efter en datters skøn faderens syn på Tyskland. Han følte bitterhed ved at skulle være soldat $\mathrm{i}$ en krig, han fandt meningsløs, og over den tvungne adskillelse fra kone og børn, som han savnede og ikke havde mulighed for at hjælpe. Ed. Jacobsen og hans brødre kom alle hjem, mens en svoger døde af følgevirkningerne af det kolde og fugtige skyttegravsophold. I mange familier savnedes manden, en far, søn eller bror. Foran Brede kirkegård blev der i genforeningsåret sat en mindesten over de 57 faldne soldater fra sognet.

Han beherskede tysk flydende, arbejdede som nyudlært murersvend rundt om i Tyskland, og bryllupsrejsen gik til Berlin på familiebesøg. Men efter krigen talte han nødig tysk, og lærte nu at skrive dansk. Med årene skærpedes hans danskhed, som besættelsen gjorde stærkere.

Hans syn på krigen tolkes måske klarest i sangen "Soldatenlied $~,{ }^{30}$ som han nedskrev under sin rekruttid: 
Soldatenlied

Ich bin Soldat, doch bin ich es nicht gerne Als ich es war hat man mich nicht gefracht Man ris mich fort hinein in di Kaserne Gefangen war ich, wi ein Wild gejacht Ja von der Heimat und des Liebchens Herzen Must ich hinweg und von der Freunde Kreis Denk ich daran fühl ich der Wehmut Schmerzen Fühl in der Brust des Zornes Glut so heis.

Ich bin Soldat doch nur mit Wiederstreben Ich liebe Ihn nicht den blauen Königsrock Ich liebe nicht das blutige Waffenleben Mich zu verteidigen wär genug ein Stock. O sagt mir doch wozu brauch Ihr Soldaten? Ein jedes Volk liebt Ruh und Frieden nur Allein aus Herschsucht und dem Volk zum Schaden Last Ihr zertreten uns di goldne Flur.

Ich bin Soldat mus Tag und Nacht marschieren. Statt an der Arbeit mus ich Posten stehn. Statt in der Freiheit mus ich salutiren. Und mus den Hochmut frecher Buben sehn. Und geht ins Feld so mus ich Brüder morden. Von denen keiner was zu Leid mir tat.

Daführ als Krüppel trag ich Band und Orden. Und hungernd ruf ich dan ich war Soldat.

Ihr Brüder all ob Deutsche ob Franzosen. Ob Ungarn, Dänen ob vom Niederland $\mathrm{Ob}$ grün ob rot ob blau ob weis di Hosen Gebt euch statt Blei zum Gruss di Bruderhand. Auf last zur Heimat uns zurück marschieren Von den Tyrannen unser Volk befrein.

Denn nur Tyrannen müssen Kriege führen. Soldat der Freiheit möcht ich gerne sein. 


\section{Andre soldaterpostkort- og breve}

På Landsarkivet for de sønderjyske Landsdele i Aabenraa og i Arkivet ved Dansk Centralbibliotek for Sydslesvig i Flensborg findes omfattende samlinger af slesvigske soldaters breve og postkort fra Vest- og Østfronten. Herfra har jeg inddraget yderligere kildemateriale for at supplere og perspektivere det materiale, artiklen primært bygger på.

Det drejer sig om personarkiver for Georg Büchert, Jaruplund, og Jes Hansen, Harreslev, i Dansk Centralbibliotek og for Thorvald Dau, Havnbjerg, Peter Lassen, Rise, og Peter Moos, Nybøl, på Landsarkivet. Samlet indeholder de godt et hundrede soldaterpostkort og et par hundrede soldaterbreve fra gårdmandssønnen Friederich Johannes Büchert til sin forlovede, familie og venner; arbejderen Nikolai Hansen og broderen Hans til svigerinden og broderen Jes Hansen; Laue Bill til vennen Peter Lassen; gårdmandssønnen Hans Moos til sine forældre og søskende, og landvæsenseleven Thorvald Dau til forældrene. Büchert døde i Rusland, mens Moos, Dau og Hans Hansen faldt på Vestfronten. Aldersmæssigt er soldaterne fra begyndelsen af tyverne til midten af tredverne. De fleste unge, ugifte og barnløse.

Postkortenes illustrationer dækker hele spektret fra billeder med skyttegrave, sønderskudte bygninger og krigsfanger over soldateropstillinger (ofte med brevskriveren på) til prospekter af gader, pladser, bygningsværker og monumenter fra soldatens tjenestested. Nogle er »kunstpostkort « med gengivelse af malerier, der viser landlige idyller, familiesamvær og harmoni. Der er kort helt uden illustrationer, men langt den overvejende del er neutrale prospektkort. Selv ikke for Nikolai Hansen, der sendte flest med krigsmotiver, overgår disse en trediedel af den samlede mængde. Dau med et halvt hundrede skrevne postkort bruger ganske få med motiver fra krigen, og alene amatørfotografier af sig selv i uniform, f.eks. i færd med at drikke kaffe i et køkken og åbne en fødevarepakke hjemmefra, øjebliksbillede af en gruppe soldaters afskedsfest og lazaretkammerater.

Kun ganske enkelte af illustrationerne på alle de undersøgte postkort virker soldaterforherligende, og ingen er af en lignende art, som de analyserede illustrationer i afsnittet »Illustrationer på kortene«. I øvrigt er kortene ikke prydet med digte, nogle dog med sentenser som "Mit Gott für König und Vaterland!« og »Gott, dir ergeb ich mich, Vater du führe mich!«.

Godt halvdelen af soldaterne skrev på dansk og de resterende tysk, selv om alle må betegnes som dansksindede. Materialet viser, at man skal være varsom med at drage slutninger om national holdning ud fra sproget. At det ikke var ganske uproblematisk at skrive dansk, skildrer Dau i gengivelsen af en samtale med sin overordnede. ${ }^{31}$ 
Den enkelte soldat er markant mindre åbenhjertig og meddelsom på postkortene end $\mathrm{i}$ brevene. Der er en betydelig større grad af lukkethed, når de meddeler sig pr. kort. Det kan ikke blot skyldes den mindre skriveplads, men må ligeledes ligge i den åbne forsendelse. Generelt indeholder kortene primært tak for pakker og breve, ønsker om at få tilsendt særlige effekter (pibe, uldent tøj o.lign.), forsikringer om at helbreddet er $\mathrm{i}$ orden, lidt om maden og vejret, lofte om snart at skrive brev og sluttelig mange hilsner til familie og venner.

Soldaterne kredser omkring orlovsproblemer, oplyser afrejseplaner og nyt opholdssted, men vigtigst fortæller de, når det går mod fronten. Kontroversielle emner tages selvsagt ikke op til diskussion på kortene. Man finder intet om danskhed, kritik af krigen eller detaljerede beskrivelser af frontlivet. Følelsesmæssige tilkendegivelser ud over hilsener er fă, undtagen hvis afrejsen til fronten var nært forestående:

Kære Venner.

Den alvorlige Time er nu kommen, da jeg maa bort til Fronten. Vi staar 500 Gardister fiks og færdig til at rykke ud. Tornystren er pakket og alt er parat. Vi blev udtaget 25 mand af mit Komp. Jeg gaar bort med frejdigt Mod, forhaabentlig kommer jeg nok hjem igen. ${ }^{32}$

Trods de generelle træk er der klare forskelle mellem soldaterne. Büchert gør på sine få kort mest konkret rede for kampe, tab af kammerater og sin sindstilstand.

Det er et trist isøde, vi er kommet til, skrækkelig på enhver måde. Vi har allerede haft mange kampe og store tab. (...)

Vi vil alle gerne tilbage, selv Lockstedt ville være et paradis i forhold til det her. ${ }^{33}$

Men en sådan grad af åbenhed er ikke almindelig. F. eks. udtrykker Nikolai Hansen sig så lapidarisk og skematisk, næsten stereotypt, at flere kort omtrent er identiske og delvis uden anden oplysningsværdi, end at han stadig er rask. Desto tydeligere fremstår undtagelsen, da han mindes broderen Hans' dødsdag: »Heute vor zwei Jahren musste unser Bruder sein Junges Leben lassen $\kappa^{34}$ Trods kortenes generelle ordknaphed får man som læser alligevel et indtryk af soldaternes individuelle personlighed.

I modsætning til postkortene er brevene ofte åbenhjertige og detaljerede, 
selv om der er divergenser mellem brevskrivernes evne og lyst til at udtrykke sig skriftligt om frontlivet og de følelsesmæssige reaktioner på krigsoplevelserne. Fra brevene bringes afslutningsvis et citatudvalg, der dels skal vise forskellene i skriftudtrykket og dels give indblik i de centrale temaer. Citaterne er markante, men giver essensen af indholdet. Udover de overordnede temaer indeholder brevene også landskabsbeskrivelser og rejseindtryk, forespørgsler om hjemlige forhold omkring høsten og fødevareforsyningen, samt mere dagligdags emner som maden, tøjet og vejret.

Det danske sindelag kommer klarest frem hos Dau og Moos. Dau var stærkt engageret i kampen for danskheden, hvilket fremgår af brevene og artiklen "I Krigens Vold«. Moos omtaler direkte længslen efter genforening kædet sammen med håbet om snarlig fred $i$ et fødselsdagsbrev til faderen:

(...) gid det nye år må bringe lykke og fred så vi snart må samles hjemme igen under ny og gode forhold, under det gamle kære flag. - Jeg har hørt og forstået af en del samtaler og igennem breve, at det håb nævnes hjemme, ja at mange er overbeviste om, at det vil ske, når vi atter har fred $\mathrm{i}$ landet. Een ting er jeg dog klar over, og det er, at hellere blive under fremmedregimente, end at vort kære hjemland skal blive hjemsøgt af krigens rædsler, eller at Danmark skal deltage i krigen. ${ }^{35}$

Den kristne tro er stærk og levende hos soldaterne, der skriver, at de forlader sig på, at Gud vil skærme og beskytte dem. Moos giver i julebrevet til sine forældre og søskende en følsom skildring af sin juleaften sammen med vennen Nikolaj. I en time, hvor de ikke havde vagt, fejrede de højtiden ved at smykke deres bord med lys og grangrene hjemmefra, samt billeder af hjem og kæreste:

Juleenglen må så være smuttet ind til os. Jeg fik det ny Testamente frem og læste juleevangeliet højt. Vi bekendte så troen og bad Fadervor, mens tårerne trillede ned ad kinderne. Vi fandt også julefred trods alt, og jeg er sikker på, at vore og Eders bønner er gåede sammen op til himlen, og julefred og juleglæde har vi også sammen, så vi trods den store afstand har haft en glad og velsignet juleaften. $^{36}$

Troen bringer ham trøst og lindring ved tanken om den svare afsked med hjemmet efter næste orlov og usikkerheden ved fremtiden. Han søger at berolige forældrene med, at afskeden nok skal gå: 
(...) med lidt godt humør og når vi forlader os på Vorherre, der har bevaret mig hidtil. Ikke en spurv falder til jorden uden hans villie. Skulde jeg blive her, var jeg et godt minde rigere, når jeg fik lov til at se Jer allesammen en gang forinden. ${ }^{37}$

Fredsønsket og krigstrætheden går igen i brevene. »Wollte Gott es wäre Friede«, ønsker Büchert og konstaterer, at ganske vist har de udkæmpet mange kampe og taget adskillige russiske krigsfanger, men med store omkostninger. Han og hans kammerater ville hellere tjene to år $\mathrm{i}$ garnisonen end føre krig én måned længere. ${ }^{38}$

Indimellem fortæller soldaterne om selvoplevede hændelsesforløb fra kamphandlingerne. Særlig interessant i denne sammenhæng er Laue Bills kortfattede skildring af et slag under offensiven i det sydlige Polen, hvor han befandt sig på samme tid som Ed. Jacobsen. Bills beskrivelse udfylder lidt af lakunen $i$ Jacobsens korrespondance: ${ }^{39}$

Fra den Gang jeg kom til Komp. og indtil nu er over Halvdelen borte. Den 20. Juli var den frygteligste Dag jeg har oplevet. Da maatte vi storme frem i Skyttelinie over et fladt Terreng paa en Strækning af $2-3 \mathrm{Km}$. mod de russiske Stillinger. Vore Soldater blev mejede ned Mand ved Mand, vi erobrede 2 Række Skyttegrave, men Slagmarken saa forfærdelig ud. Ven og Fjende laa imellem hinanden og Luften var fyldt af de Saaredes klagen og raaben om Hjælp. Vort Komp. havde denne Dag et Tab af 33. mand.

Eller udtrykt med hans ord fra Belgrad d. 5. oktober 1915:40

Mennesket kan sandelig döje og udholde meget. Det viser sig nu rigtig i denne skrækkelige Krig. Et Fjerdingaar, mage til det jeg har gjordt med i Galicien og Rusland, vilde jeg ikke gerne göre om igen. Hvad vi der har lidt og döjet lader sig neppe beskrive. (...)

Ja, kære Venner, blot vi havde Fred og kunde vende sunde og friske tilbage til det kære Nordslesvig, thi ingen Plet på Jord er skön, som du mit kære Hjem.

Træt af krigen, vemodig over afrejsen fra hjemmet og tilbagerejsen til fronten skriver han: 
(...), det var jo ganske rart at se den kære Hjemstavn en Gang igen; men de 14 Dage glider alt for hurtigt hen, det er kun en Haandevending, saa gaar det atter ud i Elendigheden, blot dette fordömte Slagteri dog snart havde en Ende, saa man kunde faa Lov til at vende hjem, for aldrig mere at drage i Krig. (...)

Gaar det ikke snart mod Enden kære Peter, jeg synes det kunde snart være nok. ${ }^{41}$

\section{LITTERATURLISTE}

Asta Hansen: Sult og sygdom. Barn i Sønderborg under 1. verdenskrig (Sønderjysk Månedsskrift 1987 , p. 269-275).

Karl Christian Lammers, Thorsten Borring Olesen og Niels Arne Sørensen: Krigsbilleder og krigsoplevelse: Soldaternes forste verdenskrig (Den jyske historiker, nr. 29-32, 1985, p. 75-120).

Krestens Breve, ved Valdemar Rørdam (Kbh. 1919).

Peter Paulson: Mit småkårsliv. Erindringer 1880-1920 (Sønderjyske Årbøger 1989, p. 235-268).

Peter Graf Kielmansegg: Deutschland und der Erste Weltkrieg (Frankfurt am Main 1968).

Ploetz: Geschichte der Weltkriege, ved Andreas Hillgruber og Jost Dülffer (Freiburg 1981).

Sønderjyske Soldaterbreve fra Øst- og Vestfronten, skrevne til Slægt og Venner i Hjemmet, ved Harald Nielsen (Kbh. 1915).

The Times Atlas of the World, Comprehensive Edition (London 1981).

Thomsen, H. Lausten: I Krigens Vold VII Thorvald Dau (Sønderjydske Aarbøger, 1930, p. 1-40).

Volksliederbuch, ved Andreas Kettel (Hamburg 1979).

\section{UTRYKT KILDEMATERIALE}

Eduard Nicolai Jacobsens personlige dokumenter, papirer og fotografier, samt hans soldaterpostkort (1915-18).

Alt i privat eje. Tak til Anna Helene Lorenzen og Helen Nielsen for lån af kildemateriale.

Landsarkivet for de Sønderjyske Landsdele, Aabenraa, private personarkiver:

nr. 135 Dau, Thorvald

nr. 448 Lassen, Peter

nr. 523 Moos, Peter

Arkivet ved Dansk Centralbibliotek for Sydslesvig, Flensborg, private personarkiver:

Arkiv P 255 Büchert, Georg

Arkiv P 279 Hansen, Jes

\section{NOTER}

1. Af pladshensyn bringes teksten kun i dansk oversættelse.

2. Ved 2. Rekruten = Depot, E./I.R.86, lagsrulle nr. 2170. Senere d.1.5.15 blev han overført til 2 . Komp. E./I.R.86. E./I.R. = Ersatz Battaillon, Infanterie Regiment.

3. Der kan være uoverensstemmelser mellem afsenderadresse og poststempel, men et par gange fremgår det, at han er på kortvarig orlov. En hilsen er poststemplet Tondern d. 22.5.17, mens afsenderadressen er MKW (Militär Kranken Wärter) Jacobsen, Res. Laz. Landsberg, z. Zeit auf Urlaub. 
4. Lægsrulle nr. 600. Tiltrædelsesdatoen var d. 17.7.15, og han fratrådte igen d. 2.8.15.

5. Datteren Anna Helene blev fodt d. 12.7.15.

6. (...) markerer, at sætninger er udeladt. Alle kortene bringes ikke i teksten, og flere kun $i$ uddrag. De er valgt og medtaget ud fra kriteriet om, at de gerne skal give et billede både af soldaten og familiefaderen: Dvs. ikke blot kort med oplysninger om lazaretophold, operation og garnisonstjeneste citeres, men også lykønskninger til hustruen og "god-bedring " hilsen til datteren. Citaterne er reprasentative udvalg for forskellige teksttyper, f.eks. medtages meddelelser om orlov og soldaternes forplejning kun enkelte gange. Ligesom faste vendinger $i$ indledninger og afslutninger medtages i begrænset omfang.

7. Stationsby øst for Krakow.

8. (?) angiver ulæselige ord, her formentlig »byen« eller »situationen«.

9. Erich von Falkenhayn (1861-1922), generalløjtnant, prøjsisk krigsminister, fra d. 14.9.14 udnævnt til tysk generalstabschef (chef for den øverste hærledelse).

10. Oplysningerne om kampdeltagelse, skader og lazaretophold er primært hentet fra Ed. Jacobsens "Militärpass«. "Militärpass'et angiver kampene udateret med undtagelse af det sidste slag, hvor han blev såret. Derfor gennemgås kampene i den rækkefølge, de står nedskrevet. Alle foregår med sikkerhed i tidsrummet fra tiltrædelsesdatoen d. 17.7 til fratrædelsesdatoen d. 2.8 (se note 4).

11. De navngivne personer er henholdsvis hans yngre bror, og en ældre invalid bror, som under krigen boede hos hans kone og børn. Vater var de yngre søskendes kælenavn for storebroderen Broder Jacobsen efter faderens tidlige død.

12. Modsat krigstjenesteanvendelig.

13. Genesenden-Kompanie var for soldater, som delvis skulle skånes.

14. Utydelig navneforkortelse, sikkert konens bror, Christian Svendsen.

15. Personerne er en bror og konens fætter, der var indkaldte, og den i note 11 omtalte ældre bror. På flere af kortene står der, at han sender brev i morgen eller blot »brev følger«. Disse breve er bortkommet.

16. Svogeren og svigerinden Christian og Franziska Svendsen, der var bosat i Berlin.

17. Om Ed. Jacobsen udførte hospitalsarbejde før er uklart. Så tidligt som d. 26.11 .16 betegnes han som »Militär Krankenwärter« i »Militärpass«'et, hvilket ikke stemmer overens med afsendertitlen "Musketier« Jacobsen d. 2.1.17.

18. Vorlaüfiger Ausweis. Reserve-Infanterie-Regiment Nr. 208. Im Felde 16.6.1918, Regimentskommandeur.

19. Besitz-Zeugnis: Verwundeten-Abzeichen. Im Felde 18.6.1918, Regiments-Kommandeur. ReserveInfanterie-Regiment Nr. 208.

20. Landsberg d. 14.1.16 og d. 22.2.18.

21. Kortets undertitel er "Der europäische Krieg 1914/15«, og er ét ud af en serie med denne motivkreds. Byen Lyck (Elk) ligger ved de masuriske søer, hvor den russiske Njemen-Armé under svære tab måtte rømme Østpreussen i september 1914, og igen i februar $1915 \mathrm{kom}$ det til vinterslaget i Masurien, hvor den russiske 10 . Armé blev slået med over 100.000 tilfangetagne.

22. For at etablere forbindelse til Tyrkiet startede centralmagterne en offensiv mod Serbien d. 6.10.15, og allerede d. 9. faldt Belgrad (Beograd).

23. Det var også Ed. Jacobsens regiment, men han deltog ikke i oktoberslaget ved Belgrad, da han var såret to måneder forinden og lå på lazaret $\mathrm{i}$ Zwickau.

24. Priesterwald er en soldaterkirkegård, der blev anvendt som motiv på ét af de øvrige ubeskrevne kort.

25. Han er registreret som sygepasser frem til d. 20.12.18.

26. Verssorgungsamt, IX Armekorps, Renten-Abteilung, Altona 25.7.1919. Svar på ansøgning af d. 11.1.19.

27. Sonderborg Invalidenævn d. 17.2.36

28. Invalideforsikringsretten, København d. 21.11.36. 
29. Asta Hansen: Sult og sygdom. Barn i Sønderborg under forste verdenskrig (Sønderjysk Månedsskrift, 1987, nr. 63) og Peter Paulson: Mit småkårsliv. Erindringer 1880-1920 (Sønderjyske Årbøger 1989).

30. Sangen er fra 0.1870 , både tekst og musik er overleveret. Ed. Jacobsen har if afskrevet teksten d. 3.4.15, og ordlyden bringes uden rettelser i denne form. Sangen findes med få ændringer i ord og stavemåde trykt i Volksliederbuch, ved Andreas Kettel (Hamburg, 1979, p. 144-145).

31. Kalisch, d. 20.3.15, „I Krigens Vold «, Sønderjydske Aarbøger 1930, p. 2.

32. Laue Bill, ved Berlin, 6.6.17.

33. Til forældrene. Stemplet 16.2.15. Gengivelse i oversat version. Bücherts træningslejr lå i Lockstedt.

34. Skrevet d. 26.8.16 (Jes Hansen, P. 279).

35. 29.4.15 (Peter Moos, nr. 523).

36. Skyttegraven. Juleaften 1914 (Peter Moos, nr. 523).

37. I Skyttegraven d. 23.4.15 (Peter Moos, nr. 523).

38. 26.2.15 (Georg Büchert, P. 255).

39. Rusland ved Lublin d. 25 juli 1915 (Peter Lassen, nr. 448).

40. Kort før slaget om Belgrad, se afsnittet om »lllustrationer på kortene« (d. Regiment 208).

41. I Felten, 1.2.17 (Peter Lassen, nr. 448). 
